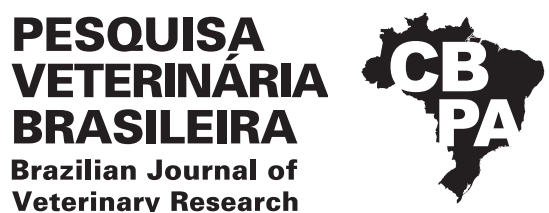

Pesq. Vet. Bras. 40(9):685-689, September 2020 DOI: 10.1590/1678-5150-PVB-6641

Original Article

inarv Research

Small Animal Diseases

ISSN 0100-736X (Print)

(cc) BY-NC

ISSN 1678-5150 (Online)

\title{
High occurrence of felid alphaherpesvirus 1 and feline calicivirus in domestic cats from southern Brazil ${ }^{1}$
}

\author{
Alice S. Becker² (D), Francielle Liz Monteiro², Ana Carolina A. Scariot ${ }^{2}$, Domitila B. \\ Chagas ${ }^{2}$, Geferson Fischer ${ }^{2}$, Marcelo de Lima $^{2}$ and Silvia O. Hübner ${ }^{2 *}$ (D)
}

\begin{abstract}
Becker A.S., Monteiro F.L., Scariot A.C.A., Chagas D.B., Fischer G., Lima M. \& Hübner S.O. 2020. High occurrence of felid alphaherpesvirus 1 and feline calicivirus in domestic cats from southern Brazil. Pesquisa Veterinária Brasileira 40(9):685-689. Laboratório de Virologia e Imunologia, Faculdade de Veterinária, Departamento de Veterinária Preventiva, Universidade Federal de Pelotas, Campus Capão do Leão, Pelotas, RS 96010-900, Brazil. E-mail: sohubner@yahoo.com.br

Felid alphaherpesvirus 1 (FeHV-1) and feline calicivirus (FCV) affect cats worldwide. The aim of this study was to evaluate the frequency of occurrence of FeHV-1 and FCV in cats with clinical signs of respiratory, oral and/or ocular disease. Samples were collected from cats cared for in veterinary ambulatory and clinics and submitted to molecular detection and viral isolation. Of the 49 cats evaluated, $45(92 \%)$ were positive for at least one of the viruses; $82 \%$ (40/49) were positive for FeHV-1 and 41\% (20/49) for FCV. Of these, 31\% $(15 / 49)$ were coinfection cases. For FeHV-1, 45\% (18/40) of the cats tested were positive from the collection of eye swab, and the same percentage $(9 / 20)$ was obtained for the FCV by the oral swab. FeHV-1 and/or FCV were isolated in 35\% (17/49) of the samples. The main clinical sign observed was ocular secretion in $71 \%$ (35/49) of cats, characterized as mild serous, purulent or serosanguineous, and in some cases associated with ocular injury and marked chemosis. Our findings demonstrate the high occurrence of FeHV-1 and FCV in domestic cats in southern Brazil and indicate that measures should be implemented to improve the diagnostic, prevention and management against of these important diseases.
\end{abstract}

INDEX TERMS: Felid alphaherpesvirus 1, feline calicivirus, domestic cats, Brazil, cat, feline respiratory disease complex, FRDC, FCV, FeHV-1.

RESUMO.- [Alta ocorrência de alphaherpesvirus felideo e calicivirus felino em gatos domésticos no Sul do Brasil.] Alphaherpesvírus felídeo 1 (FeHV-1) e calicivírus felino (FCV) afetam gatos mundialmente. 0 objetivo deste estudo foi identificar a frequência de ocorrência de FeHV-1 e FCV em gatos com sinais clínicos de doença respiratória, oral e/ ou ocular. Amostras foram coletadas de gatos atendidos em ambulatório e clínicas veterinárias e submetidas à detecção molecular e isolamento viral. Dos 49 gatos avaliados, 45 (92\%) foram positivos para ao menos um dos vírus; $82 \%$ (40/49) foram positivos para o FeHV-1 e 41\% (20/49) para o FCV. Destes, 31\% (15/49) foram casos de coinfecção. Para o FeHV-1, 45\% (18/40) dos gatos foram positivos na coleta do $s w a b$ ocular, e o mesmo percentual $(9 / 20)$ foi obtido para

\footnotetext{
${ }^{1}$ Received on March 18, 2020.

Accepted for publication on April 3, 2020.

${ }^{2}$ Laboratório de Virologia e Imunologia, Faculdade de Veterinária, Universidade Federal de Pelotas (UFPel), Campus Capão do Leão, Pelotas, RS 96010-900, Brazil. *Corresponding author: sohubner@yahoo.com.br
}

o FCV a partir do swab oral. FeHV-1 e/ou FCV foram isolados em 35\% (17/49) das amostras. O principal sinal clínico observado foi secreção ocular em 71\% (35/49) dos gatos, caracterizada como serosa, purulenta ou serossanguinolenta e, em alguns casos, associada à lesão e quemose. Nossos resultados demonstram a alta ocorrência de FeHV-1 e FCV em gatos domésticos na região Sul do Brasil e indicam que devem ser implementadas medidas para melhorar o diagnóstico, a prevenção e o manejo contra essas importantes doenças.

TERMOS DE INDEXAÇÃO: Alphaherpesvírus felídeo, calicivírus felino, gatos domésticos, Brasil, gato, complexo respiratório felino, CRF, FCV, FeHV-1.

\section{INTRODUCTION}

Felid alphaherpesvirus 1 (FeHV-1) and feline calicivirus (FCV) are a frequent cause of diseases in the domestic feline population. Transmission occurs through nasal, ocular and oral discharges, by direct contact between cats, or even by 
fomites (Cohn 2011). Both agents are distribuited worldwide, with higher prevalence in settings where large numbers of cats coexist, including animal shelters and colonies (Radford et al. 2009, Thiry et al. 2009). FeHV-1 is a double-stranded DNA virus that belongs to the family Herpesviridae (Gaskell et al. 2007, ICTV 2018). Like other agents of the family, the significant characteristic of the virus is the establishment of latent infection, in this case occurring in the trigeminal ganglia (Gaskell et al. 2007). FeHV-1 causes clinical signs like nasal and ocular discharge, conjunctivitis and keratitis, with dendritic corneal ulcers as its pathognomonic clinical sign. Other clinical signs like pneumonia, facial dermatitis, stomatitis and meningoencephalitis are also described (Hora et al. 2013, McGregor et al. 2016, Rodriguez et al. 2016, Argenta et al. 2017, Porcelatto et al. 2018).

FCV is a single-stranded positive sense RNA virus, belonging to the family Caliciviridae (ICTV 2018). It is a non-enveloped agent, being highly resistant in the environment (Meyers et al. 1991, Radford et al. 2007, 2009). Some cats remain asymptomatic carriers after acute infection of FCV, being a source of infection for other susceptible cats (Gaskell et al. 2007). FCV is associated with different clinical patterns, including respiratory symptoms, oral ulcerations, and gingivitis/ stomatitis (Afonso et al. 2017, Nakanishi et al. 2018).

Knowledge of the major viruses circulating in a region is fundamental to establish of prevention and control measures. Thus, the present study aimed at identifying the frequency of occurrence of FeHV-1 and FCV in cats from southern Brazil.

\section{MATERIALS AND METHODS}

Animals and samples. Samples were collected during January to June of 2019 from 49 cats from veterinary clinics and an ambulatory associated to the "Universidade Federal de Pelotas" (UFPel) in the city of Pelotas (Latitude: 3146'19” S, Longitude: 52²0'33” W), located in southern Rio Grande do Sul (Brazil). Information regarding sex, age and clinical manifestations were obtained from each animal. The experiments were approved by the Institutional Committee on Animal Welfare and Ethics (UFPel - approval number 57742-2018).

The samples consisted of conjunctival, nasal and oral/oropharyngeal swabs collected from cats with clinical signs like conjunctivitis, ocular and nasal discharges, sneezing, coughing, oral ulcers and gingivitisstomatitis complex (CGS). The swabs were immersed in $0.5 \mathrm{~mL}$ of minimum essential medium (MEM) and immediately processed or stored in RNAlater ${ }^{\text {TM }}$ Stabilization Solution (Invitrogen ${ }^{\text {TM }}$, EUA) and maintained at $-70^{\circ} \mathrm{C}$ until use. $0.2 \mathrm{~mL}$ was used for viral isolation in cell culture and $0.15 \mathrm{~mL}$ for extraction of nucleic acids (DNA or RNA).

Cell culture and virus isolation. The feline kidney cell line CRFK (Crandell-Reese feline kidney) was used for isolation and amplification of the viruses. Cells were routinely maintained in MEM supplemented with $10 \%$ fetal bovine serum, containing antibiotics and antifungal (penicillin 200.000UI/L, streptomycin 200mg/L, enrofloxacin $5 \mathrm{mg} / \mathrm{L}$ and amphotericin B $2.5 \mathrm{mg} / \mathrm{L}$ ). The swabs were subjected to vortex and the content was then transferred to tubes and centrifuged at $3.000 \mathrm{x}$ g for 3 minutes. The supernatants were inoculated onto CRFK cell monolayers grown in 24-well plates and were submitted to three passages of five days each, while the cells were monitored for cytopathic effect. The strains B927 FeHV-1 and SV1425/93 FCV were used as positive controls (provided from Instituto de Pesquisas Veterinárias Desidério Finamor - IPVDF, Porto Alegre/RS and "Setor de Virologia", of the "Universidade Federal de
Santa Maria", Santa Maria/RS) and cells with only MEM were used as negative control.

Nucleic acid extraction and PCR. DNA extractions were performed using ReliaPrep ${ }^{\mathrm{TM}}$ Viral Total Nucleic Acid Extraction (Promega, Wisconsin, EUA), according to the manufacturer's instructions. DNA was submitted to PCR assay for the thymidine kinase enzyme (TK) gene, using the primers Herp_F: 5'-GACGTGGTGAATTATCAGC-3' and Herp_R: 5'-CAACTAGATTTCCACCAGGA-3' (Sykes et al. 1998). The conditions were: $94^{\circ} \mathrm{C}$ for 5 minutes, 40 cycles of 94,56 and $72^{\circ} \mathrm{C}$ for 45,30 and 45 seconds, respectively, and $72^{\circ} \mathrm{C}$ for 7 minutes.

RNA extraction was performed using TRIzol ${ }^{\circledR}$ Reagent, according to the manufacturer's instructions. After RNA extraction, complementary DNA (cDNA) was synthesized using iScript ${ }^{\text {TM }}$ cDNA Synthesis (Bio-Rad). Briefly, total RNA ( 500ng) was mixed with $5 x$ Reaction Mix and $1 U$ Reverse Transcriptase. The samples were incubated for 5 minutes at $25^{\circ} \mathrm{C}$, followed by incubation at $46^{\circ} \mathrm{C}$ for 20 minutes and $95^{\circ} \mathrm{C}$ for 1 minute. The synthesized cDNAs were submitted to Nested PCR assay for A-B conserved region of ORF2 (capsid protein gene), using the primers Cali1: 5'AACCTGCGCTAACGTGCTTA-3', Cali2: 5' - CAGTGACAATACACCCAGAAG -3', and at second round, Cali3: 5' - TGGTGATGATGAATGGGCATC -3' and Cali4: 5' - ACACCAGAGCCAGAGATAGA-3' (Marsilio et al. 2005). The conditions were: $94^{\circ} \mathrm{C}$ for 3 minutes, 35 cycles of 94,50 and $72^{\circ} \mathrm{C}$ for 1 minute, 45 seconds and 1 minute, respectively, and $72^{\circ} \mathrm{C}$ for 7 minutes.

The PCR reaction was performed in a $25 \mu \mathrm{L}$ volume, using 100 200 ng of DNA or cDNA template, $1 x_{\text {GoTaq }}^{\circledR}{ }^{\circledR}$ Colorless Master Mix (Fitchburg, Wisconsin, EUA) and $0.4 \mu \mathrm{M}$ of each primer. RNA extracted from the CRFK was used as negative control and strains B927 and SV1425/93 were used as control of FeHV-1 and FCV, respectively. PCR products of FeHV-1 and RT-PCR of FCV were resolved in a 1.5\% agarose gel stained (Blue Green Loading Dye I, LGC Biotecnologia, São Paulo, BR) and visualized under ultraviolet (UV) light after electrophoresis (100V, 40 minutes).

Sequencing analysis. PCR products were purified using PureLink ${ }^{\circledR}$ Quick Gel Extraction and PCR Purification Combo Kit (Life Technologies, CA, USA). Positive samples were sequenced in duplicate using the BigDye kit. Results were analyzed by the Staden program (Staden 1996) to obtain a consensus sequence, and the alignment of sequences with those from GenBank and identity matrix was performed using the BioEdit Sequence Alignment Editor Software suite 7.0.5.3. The translation of a nucleotide sequence to a protein sequence was performed using the ExPASy Bioinformatics ${ }^{3}$.

\section{RESULTS AND DISCUSSION}

Samples of eye, oral/oropharyngeal and nasal swabs were obtained from 49 symptomatic cats located in the South of Brazil, during the period of January to June of 2019. According to age, 20 animals were classified as kittens $(<1$ year), nine as young (1-2 years), 15 as adults (3-7 years) and five as elders ( $\geq 8$ years), and consisted of 32 males and 17 females. Regarding vaccination status, only $4 \%(2 / 49)$ were vaccinated, $71 \%(35 / 49)$ were not vaccinated and $24 \%(12 / 49)$ had unknown vaccination status. Besides, $67 \%$ (33/49) of the animals had outdoor access.

All samples collected were evaluated by PCR for FeHV-1 and nested RT-PCR for FCV. FeHV-1 amplified product in PCR resulted in a fragment of $287 \mathrm{bp}$. FCV amplified product in

$\overline{3}$ Available at $<$ https://web.expasy.org/translate/ $>$ 
Nested RT-PCR resulted in a 924bp fragment in first round, and a $467 \mathrm{bp}$ fragment in the second round. Of the 49 cats, 45 $(92 \%)$ were positive for at least one of the viruses. Among the positive animals, were $100 \%$ (20/20) of the kittens, $100 \%$ $(9 / 9)$ of the young ones, $73.3 \%(11 / 15)$ of the adults and $100 \%(5 / 5)$ of the elders. Besides, $88.5 \%(31 / 35)$ of the not vaccinated group were positive, $100 \%(2 / 2)$ of the cats with no historical of previous vaccination and $100 \%(12 / 12)$ of the cats with unknown vaccination status. Among the animals without outdoor access, 75\% (3/4) were positive, along with $100 \%(33 / 33)$ of the cats with outdoor access and 75\% (9/12) of the animals where this information was not available.

For FeHV-1, 82\% (40/49) were positive, and for FCV, $41 \%(20 / 49)$ of positivity was obtained. Thirty one percent $(15 / 49)$ were cases of coinfection. These results demonstrate a high occurrence of these viruses in the studied population, especially regarding FeHV-1. Besides, these data are higher than what is described in Germany (Schulz et al. 2015), Spain (Fernandez et al. 2017), and Australia (Nguyen et al. 2018), where molecular detection studies involving symptomatic animals were also conducted, showing wide variations in the detection of these agents according to different geographic regions. The rate of occurrence detected in our study indicates the high circulation of these viruses in this region, which could be explained by the outdoor lifestyle and the unvaccinated status of the majority of the animals. Vaccines for FeHV-1 and FCV are essential for all cats (Day et al. 2016) and considered effective in reducing clinical signs and viral excretion, although they are not capable to completely avoid infection and transmission of the agents (Radford et al. 2009, Thiry et al. 2009). In addition, protection by vaccination against FCV may be affected by the high variability of existing strains (Radford et al. 2009). Thus, even vaccinated animals can be infected and act as carriers, spreading these agents.

In Southern Brazil, previous serological studies detected FCV and FeHV-1 in the feline population, both in vaccinated and non-vaccinated animals (Johann et al. 2009, Henzel et al. 2013). During the years from 2006 to 2009, a study was conducted to identify feline calicivirus and feline herpesvirus in southern Brazil, evaluating both symptomatic and asymptomatic cats, which makes it difficult to compare their results to the ones found in the present study. This same study found $38.2 \%(21 / 55)$ of positivity for FeHV-1 and $52.7 \%$ (29/55) for FCV, with co-infection in 9.1\% (5/55) (Henzel et al. 2012).

Our data show a higher occurrence of FeHV-1 compared to FCV. This result can be partly explained by FeHV-1 pathogenesis. FeHV-1 remains latent in infected animals, and eventually, mainly in cases of immunosuppression or stressful conditions, returns to the lytic cycle and is reexcreted in the primary sites of infection. Possibly, the FeHV-1 detected in these cats was the cause of acute clinical signs due primary infection, but also, especially in adult cats, FeHV-1 developed the disease at the time of viral reactivation. The disease as a consequence of virus recrudescence may be consequence of immunosuppression caused by other factors or diseases that were not investigated. FCV, on the other hand, can be detected in healthy animals due to the carrier state that occurs in some animals. In these cases, the virus remains replicating and being eliminated through secretions, although no apparent symptomatology is identified (Radford et al. 2009). Anyway, the data clearly show high circulation and occurrence of FeHV-1 and FCV in the studied population.

The virus was isolated in 35\% (17/49) of the cats, being $47 \%$ (8/17) from oral swabs, $29 \%$ (5/17) ocular swab, $18 \%$ $(3 / 17)$ from the eye and oral swab, and 6\% (1/17) from the oral and nasal swab. Figure 1 shows the FeHV-1 and FCV molecular detection according to the place of swab collection (oral/oropharyngeal, ocular or nasal regions). For FeHV-1, $45 \%(18 / 40)$ of the cats were positive from the collection of eye swab, and the same percentage $(9 / 20)$ was obtained for the FCV from the oral swab. In $27.5 \%$ (11/40) of animals positive for FeHV-1 and 30\% (6/20) positive for FCV, virus detection was possible from both oral and eye swab. These results corroborate with previous studies, where the main FCV detection location was from the oral/oropharyngeal mucosa (Schulz et al. 2015). However, in this same study, no difference was observed among the collection sites for FeHV-1, suggesting oral/oropharyngeal swab as the sample of choice for the detection of both viruses. The results obtained in the present study highlight the importance to collect samples from more than one region, in order to increase the possibility of detecting the agents. The detection of FeHV-1 and/or FCV from nasal swabs was only possible in four animals, possibly due to the greater difficulty encountered at the time of sampling of the mucosa, a fact that was also reported by Schulz et al. (2015).

Figure 2 show the clinical signs observed in animals evaluated. Ocular secretion was observed in $71 \%(35 / 49)$ of cats and was characterized as mild serous, purulent or

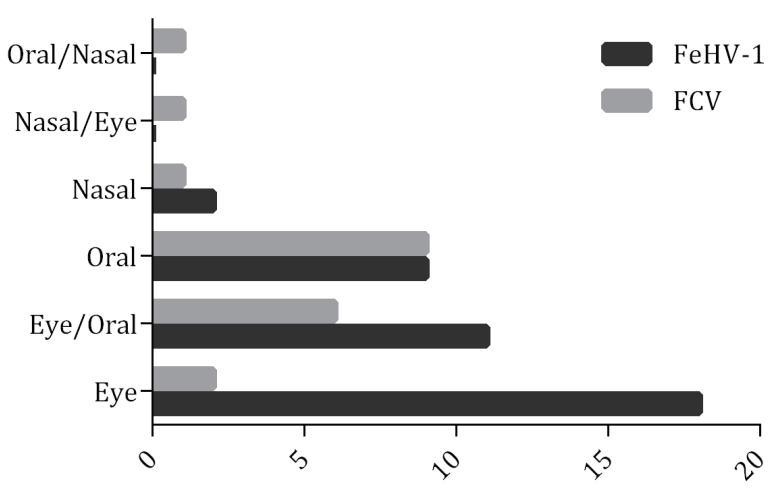

Fig.1. Felid alphaherpesvirus-1 and feline calicivirus molecular detection according to swab collection site in 49 cats from southern Brazil. Numbers refers to the number of cats that tested positive in each site.

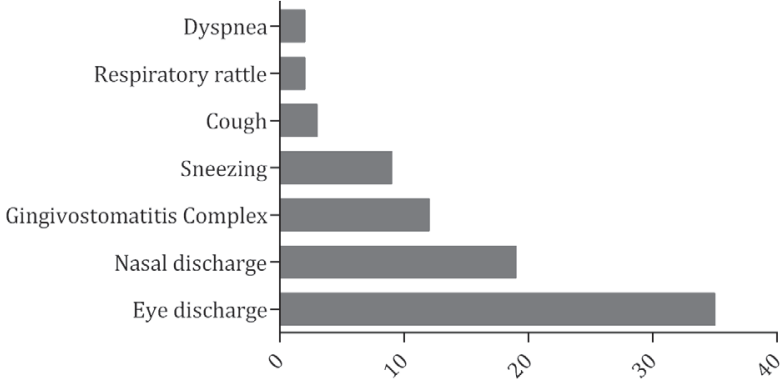

Fig.2. Clinical signs observed in 49 symptomatic cats evaluated. Numbers refers to the number of cats presenting each clinical sign. 
serosanguineous, and in some cases associated with ocular injury and marked chemosis. The second most frequent clinical sign was nasal discharge in 39\% (19/49) of cats, ranging from mild serous to purulent, followed by CGS in $24 \%(12 / 49)$, sneezing in $18 \%(9 / 49)$, cough in 6\% (3/49), respiratory rattle in $4 \%(2 / 49)$ and dyspnea in $4 \%(2 / 49)$. The main clinical sign in FCV-positive animals was CGS, identified in 58\% (7/12) of the animals. Despite CGS having multifactorial causes (Lyon 2005), it is often associated with FCV (Fernandez et al. 2017, Thomas et al. 2017, Nakanishi et al. 2018). FeHV-1, on the other hand, was detected in $50 \%$ $(18 / 36)$ of animals exhibiting nasal and/or ocular secretion. To compare, Fernandez et al. (2017) detected FeHV-1 in 28\% (36/127) of animals showing clinical signs related to upper respiratory tract disease and 24\% (36/149) of animals with conjunctivitis. It is known that other agents may be involved in respiratory and/or ocular disease in cats, also called "feline respiratory disease complex" (FRDC), especially Bordetella bronchiseptica and Clamidophyla felis (Cohn 2011). Clinical signs in these cases are similar to FeHV-1 or FCV infection, and can cause confusion. Symptomatic animals in our study that were negative for both FeHV-1 and FCV could have an infection by these other agents. Our study shows that the most common pathogens associated with FRDC in southern Brazil are FeHV-1 and FCV.

The PCR product of FeHV-1 was sequenced and subjected to analysis, showing nucleotide (nt) identity of 99.7 to $100 \%$ with FeHV-1 sequences deposited with GenBank. Analysis about the nt and amino acid (aa) identity performed with isolated FCV detected high genetic variability in comparison with vaccine strain $\mathrm{F} 9$, ranging from 76.1 to 77.4 (nt) and 87.4 to 88.9 (aa), even though the more conserved regions of FCV capsid (regions A and B) were analyzed. This result may serve as an alert to possible vaccine failures in this region. In general, the level of heterologous protection will depend on the virus strains involved (Radford et al. 2009). Analysis about the $n t$ and $a a$ identity between the FCV sequences in this study was 88.8 to $97.4 \%$ and 99.2 to $100 \%$, respectively.

\section{CONCLUSIONS}

Our findings demonstrate high occurrence of Felid alphaherpesvirus 1 and Feline calicivirus in domestic cats in southern Brazil. This information can be used to improve measures about diagnostic, prevention and management against these important cat diseases.

Acknowledgements.- The publication of this paper was partially supported by PRPPGI/UFPel and CAPES. F.L. Monteiro was the recipient of the "Programa Nacional de Pós-Doutorado" (PNPD), "Coordenação de Aperfeiçoamento de Pessoal de Nível Superior” (CAPES) fellowship.

Conflict of interest statement.- The authors declare that they have no conflict of interest.

\section{REFERENCES}

Afonso M.M., Pinchbeck G.L., Smith S.L., Daly J.M., Gaskell R.M., Dawson S. \& Radford A.D. 2017. A multi-national European cross-sectional study of feline calicivirus epidemiology, diversity and vaccine cross-reactivity. Vaccine 35(20):2753-2760. <http://dx.doi.org/10.1016/j.vaccine.2017.03.030> $<$ PMid:28389099>
Argenta F.F., Ramos B.C., Fredo G., Laisse C.J.M., Rolim V.M., Cargnelutti J.F., Flores E.F., Pavarini S.P., Costa F.V.A. \& Driemeier D. 2017. Ulcerative dermatitis caused by feline herpesvirus type 1 in a domestic cat. Semina, Ciênc. Agrárias, 38(supl.1):2857-2862. <http://dx.doi.org/10.5433/16790359.2017v38n4Supl1p2857>

Cohn L.A. 2011. Feline respiratory disease complex. Vet. Clin. N. Am., Small Anim. Pract. 41(6):1273-1289. <http://dx.doi.org/10.1016/j. cvsm.2011.07.006><PMid:22041216>

Day M.J., Horzinek M.C., Schultz R.D. \& Squires R.A. 2016. Guidelines for the vaccination of dogs and cats - Compiled by the Vaccination Guidelines Group (VGG) of the World Small Animal Veterinary Association (WSAVA). J. Small Anim. Pract. 57:E1-E45.

Fernandez M., Manzanilla E.G., Lloret A., León M. \& Thibault J.C. 2017. Prevalence of feline herpesvirus-1, feline calicivirus, Clamidophyla felis and Mycoplasma felis DNA and associated risk factors in cats in Spain with upper respiratory tract disease, conjunctivitis and/or gingivostomatitis. J. Feline Med.Surg. 19(4):461-469. <http://dx.doi.org/10.1177/1098612X16634387> <PMid:26919892>

Gaskell R., Dawson S., Radford A. \& Thiry E. 2007. Feline herpesvirus. Vet. Res. 38(2):337-354. <http://dx.doi.org/10.1051/vetres:2006063> <PMid:17296160>

Henzel A., Brum M.C.S., Lautert C., Martins M., Lovato L.T. \& Weiblen R. 2012. Isolation and identification of feline calicivirus and feline herpesvirus in Southern Brazil. Braz. J. Microbiol. 43(2):560-568. <http://dx.doi. org/10.1590/S1517-83822012000200017>

Henzel A., Brum M.C.S., Lovato L.T. \& Weiblen R. 2013. Serological survey of feline calicivirus and felid herpesvirus in Rio Grande do Sul, Brazil. Acts Sci. Vet. 41:1-6.

Hora A.S., Tonietti P.O., Guerra J.M., Leme M.C., Pena H.F.J., Maiorka P.C. \& Brandão P.E. 2013. Felid herpesvirus 1 as a causative agent of severe nonsuppurative meningoencephalitis in a domestic cat. J. Clin. Microbiol. 51(2):676-679. <http://dx.doi.org/10.1128/JCM.02462-12> <PMid:23152556>

ICTV 2018. International Committee on Taxonomy of Viruses. Available at <https://talk.ictvonline.org> Accessed on 2018.

Johann J.M., Caetano C.F., Hass R., Guim T.N., Fischer G., Vargas G.D., Vidor T. \& Hübner S.0. 2009. Serum survey for antibodies to coronavirus, herpesvirus, calicivirus, and parvovirus in domestic cats from Rio Grande do Sul, Brazil. Arq. Bras. Med. Vet. Zootec. 61(3):752-754. <http://dx.doi.org/10.1590/ S0102-09352009000300033>

Lyon K.F. 2005. Gingivostomatitis. Vet. Clin. N. Am., Small Anim. Pract. 35(4):891911. <http://dx.doi.org/10.1016/j.cvsm.2005.02.001><PMid:15979518>

Marsilio F., Di Martino B., Decaro N. \& Buonavoglia C. 2005. A novel nested PCR for the diagnosis of calicivirus infections in the cat. Vet. Microbiol. 105(1):1-7. <http://dx.doi.org/10.1016/j.vetmic.2004.09.017><PMid:15607078>

McGregor G.F., Sheehan K. \& Simko E. 2016. Pneumonia and gastritis in a cat caused by feline herpesvirus-1. Can. Vet. J. 57(2):147-150.<PMid:26834264>

Meyers G., Wirblich C. \& Thiel H.J. 1991. Rabbit hemorrhagic disease virus-molecular cloning and nucleotide sequencing of a calicivirus genome. Virology. 184(2):664-676. <http://dx.doi.org/10.1016/0042-6822(91)90436-f> $<$ PMid:1840711>

Nakanishi H., Furuya M., Soma T., Hayashiuchi Y., Yoshiuchi R., Matsubayashi M., Tani H., Sasai K. 2018. Prevalence of microorganisms associated with feline gingivostomatitis. J. Feline Med. Surg. 21(2):103-108. <http://dx.doi. org/10.1177/1098612X18761274><PMid:29504825>

Nguyen D., Barrs V.R., Kelman M. \& Ward M.P. 2018. Feline upper respiratory tract infection and disease in Australia. J. Feline Med. Surg. 21(10):973-978. <http://dx.doi.org/10.1177/1098612X18813248> <PMid:30465616>

Porcelatto I., Luciani L., Marenzoni M.L., Santagostino S.F., Sforna M., Mechelli L. \& Brachelente C. 2018. Feline herpesvirus ulcerative dermatitis: an atypical case? Vet. Dermatol. 29(3):258-e96. <http://dx.doi.org/10.1111/ vde.12537><PMid:29624750> 
Radford A.D., Addie D., Belák S., Boucraut-Baralon C., Egberink H., Frymus T., Gruffydd-Jones T., Hartmann K., Hosie M.J., Lloret A., Lutz H., Marsilio F., Pennisi M.G., Thiry E., Truyen U. \& Horzinek M.C. 2009. Feline calicivirus infection: ABCD guidelines on prevention and management. J. Feline Med. Surg. 11(7):556-564. <http://dx.doi.org/10.1016/j.jfms.2009.05.004> <PMid:19481035>

Radford A.D., Coyne K.P., Dawson S., Porter C.J. \& Gaskell R.M. 2007. Feline calicivirus. Vet. Res. 38(2):319-335. <http://dx.doi.org/10.1051/ vetres:2006056>

Rodriguez J.M.M., Leeming G., Köhler K. \& Kipar A. 2016. Feline herpesvirus pneumonia: investigations into the pathogenesis. Vet. Pathol. 54(6):922932.<http://dx.doi.org/10.1177/0300985817720982><PMid:28812530>

Schulz C., Hartmann K., Mueller R.S., Helps C. \& Schulz B.S. 2015. Sampling sites for detection of feline herpesvirus-1, feline calicivirus and Chlamydia felis in cats with feline upper respiratory tract disease. J. Feline Med. Surg. 17(12):1012-1019. <http://dx.doi.org/10.1177/1098612X15569615> <PMid:25660223>
Staden R. 1996. The Staden sequence analysis package. Mol. Biothecnol. 5(3):223-241.<http://dx.doi.org/10.1007/BF02900361><PMid:8837029>

Sykes J.E., Studdert V.P. \& Browing G.F. 1998. Detection and strain differentiation of feline calicivirus in conjunctival swabs by RT-PCR of the hypervariable region of the capsid protein gene. Arch. Virol. 143(7):1321-1334. <http://dx.doi.org/10.1007/s007050050378> <PMid:9722877>

Thiry E., Addie D., Belák S., Boucraut-Baralon C., Egberink H., Frymus T., Gruffydd-Jones T., Hartmann K., Hosie M. J., Lloret A., Lutz H., Marsilio F., Pennisi M.G., Radford A.D., Truyen U. \& Horzinek M.C. 2009. Feline Herpesvirus Infection: ABCD guidelines on prevention and management. J. Feline Med. Surg. 11(7):547-555. <http://dx.doi.org/10.1016/j.jfms.2009.05.003> <PMid:19481034>

Thomas S., Lappin D.F., Spears J., Bennett D., Nile C. \& Riggio M.P. 2017. Prevalence of feline calicivirus in cats with odontoclastic resorptive lesions and chronic gingivostomatitis. Res. Vet. Sci. 111:124-126. <http://dx.doi. org/10.1016/j.rvsc.2017.02.004> 